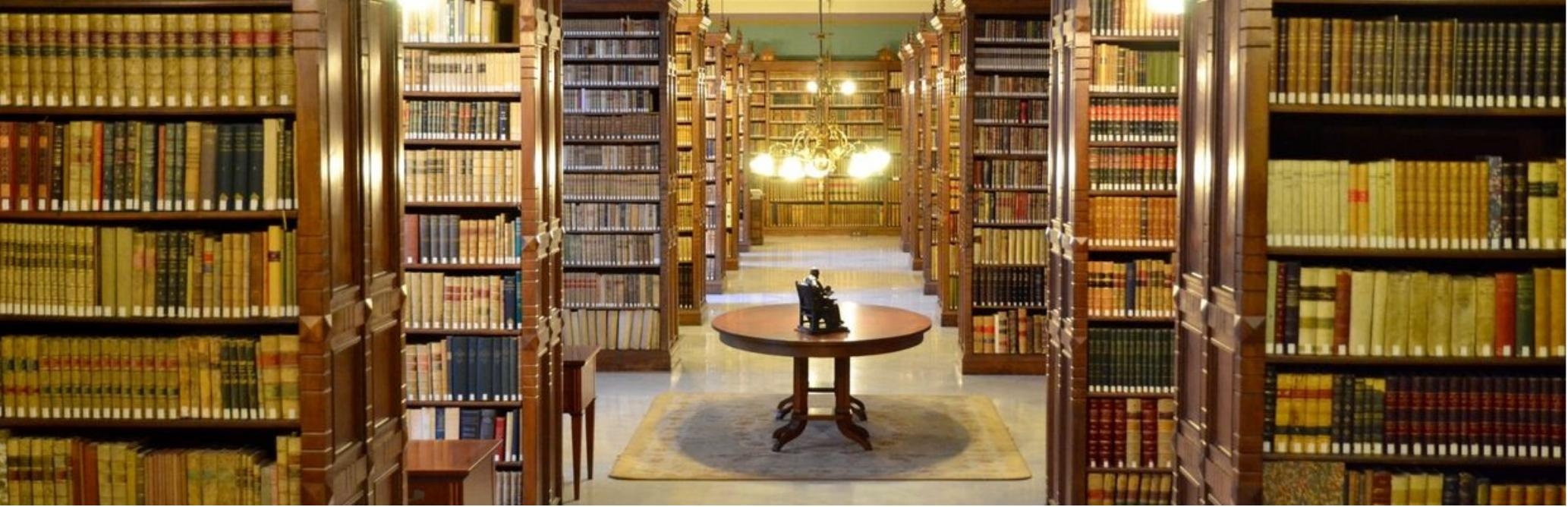

\title{
Editorial Volume 6, Issue 9
}

$\begin{aligned} \text { Authors: } & \text { María Fernanda Sandoval } \\ \text { Submitted: } & \text { 1. October } 2019 \\ \text { Published: } & 4 \text {. October } 2019 \\ \text { Volume: } & 6 \\ \text { Issue: } & 9 \\ \text { Affiliation: } & \text { IASHA e.V., Freiburg, Germany } \\ \text { Languages: } & \text { English } \\ \text { Keywords: } & \text { Editorial, Josha Journal, 2019, September } \\ \text { Categories: } & \text { News and Views } \\ \text { DOI: } & 10.17160 / \text { josha.6.9.604 }\end{aligned}$

Abstract:

This editorial concludes issue 9 of September 2019. All together we had the honor to present and publish five different articles from the fields of medicine, scientific research, visual arts in the field of architecture and the arts within the world of classical music. We have closed the column series of Dr. Leander Hotaki with his last column in a total of seven as a small impulse for our readers out there who are looking forward to publishing their opinions in all fields of science, humanities or arts. Not being this everything, we also have had the pleasure to be working with an excellent Journal that shares the ideal of many scientists, the idea of exploring possible phenomena located around us as a way of understanding what we do. The journal El Gato y La Caja, sees the world and knowledge similar to the way JOSHA sees it, sharing and communicating Information through an open-access plattform. 


\section{JOSHA - Journal of Science Humanities and Arts Editorial Volume 6 Issue 9}

This editorial concludes issue 9 of September 2019. All together we had the honor to present and publish five different articles from the fields of medicine, scientific research, visual arts in the field of architecture and the arts within the world of classical music. We have closed the column series of Dr. Leander Hotaki with his last column in a total of seven as a small impulse for our readers out there who are looking forward to publishing their opinions in all fields of science, humanities or arts. Not being this everything, we also have had the pleasure to be working with an excellent Journal that shares the ideal of many scientists, the idea of exploring possible phenomena located around us as a way of understanding what we do. The journal El Gato y La Caja, sees the world and knowledge similar to the way JOSHA sees it, sharing and communicating Information through an open-access plattform.

\section{MUSIC \& ARTS}

The first article of this month "Digitaler Klang? - Digital sound?" represents the entire publication of a total of 7 columns written by Leander Hotaki, who is since 2010 the director of the German program called "Albert Konzerte" which is a program in charge of making possible to bring the greatest artist of the World to Freiburg and to make the most wonderful concerts in the south-west of Germany. In fact, he also promotes the work of the best students in the field of dramaturge or music in many universities in Germany. Each of his columns involves a particular Musical theme. in some cases, for example, he talks about the difficult reality regarding the burden borne by musicians born into families of world-renowned singers or instrumentalists. among so many themes, he also covers in detail the technological advances within musical productions and the positive impact of this musical technological evolution on the environment.

\section{VISUAL ARTS \& ARCHITECTURE}

Subsequently, in the area of visual arts, more precisely in architecture, we have presented the work of Prof. Bujar Bajçinovci and Mejreme Bajçinovci of the University of Prishtina in Kosovo, who within the framework of the contribution to the environment, holds some options and solutions that allow improving the infrastructure in Kosovo, taking care of and repeating the environment. The article was entitled "Fridays for Future - Urban Urgency for Air Quality and E-Vehicles: A Case of Prishtina" and has as a principal topic the factual situation of parking spaces in Pristina is problematic. The shortcoming of a sustainable urban mobility plan for the city of Pristina and its linkage to spatial plans in the future will bring serious problems for the city, which will have a negative impact on the quality of life.

\section{MEDICINE AND MACHINE LEARNING}

In the second article, we change to the area of scientific research, in which Julieta Alcain set out to expose with data and results some of the experiences lived by different scientists at the time of the repetition of certain 
experiments. "El Agite", which has been previously published by the journal EL Gato y La Caja from Argentina, is questioned which must have been the error in all these experiments that did not allow the scientists to conclude in the same result repeated times? The translation of this same article into English "Reproducibility Crisis in the Sciences: The "Agitation" " was carried out with the purpose of buying so interesting and relevant for all those who spend their day to day in a scientific laboratory, as well as for those who are simply interested in current situations in the world of science.

Finally, also within the area of research, but closer to medicine and technology, we present to you the description of the degree work carried out by Simon Woitzik together with Roland Mertelsmann and Reinhard Marks entitled "Harnessing knowledge AND clinical experience to improve patient care employing an electronic system analyzing non-structured medical records: The "SimRec" Software".

We are happy to carry on a successful way with all your support and hope to have a wonderful Sommer overflowing with endless interesting articles from all over the world. Together, we have achieved so much exile in such a short time. Therefore, we thank you and promise to continue to work to connect more authors around the world and continue to share important knowledge, because the knowledge that is not communicated is wasted knowledge!

The Editorial Board and everybody in JOSHA would like to thank our readers and authors for supporting this project. We wish all our readers a joyful reading experience at JOSHA!

Table of content: http://josha-journal.org/en/issues

Maria Sandoval on behalf of the JOSHA Team 